\title{
Effects of the Patriarchal Mentality on Domestic Violence Appearance in the Region of Elbasan, Albania
}

\author{
Darina Çoni( Kacollja) \\ Lagjia nr 8 Rruga Aleksander Goga \& Mitrush Kuteli, Pallati " Turkeshi" Durres, Albania \\ darinakacollja@yahoo.com
}

Doi:10.5901/ajis.2014.v3n3p306

\begin{abstract}
The violence toward women in Elbasan district, Albania. The violence toward women in Elbasan district is very concerning and too evident. This situation is proved to be true even by the study realized in this district. In order to realize this study, two questionnaires were filled by 1200 persons included of different ages such as 13-23 years old and 18-60 years old. These questionnaires were delivered in these cities: Elbasan, Peqin, Gramsh and Librazhd. The factors that have an influence on the violence toward women are the patriarchal mentality, the low economic state, communication, the usage of alcoholic drinks, etc. The factors that cause violence might be various, but the violence of gender reason in each society is unjustifiable. If we accept the violence of gender reason, we can accept even the violence for religion reasons, the violence according to the origin, the people can be divided into groups and can accept violence according to each division. One of the main reasons of violence in the Elbasan district is Mediterranean patriarchal mentality, which is more widespread in the rural areas.
\end{abstract}

Keywords: Violence, woman, male, patriarchal, violence, Elbasani district.

"The patriarchal ideology represents the women subjugation as something natural, right and desired which contributes in making the oppressed to accept or not see the real domination" (Romito, P., 2007:53). This patriarchal ideology has been very developed in the region of Elbasan, as well as in the entire country, especially before 1945, an ideology which continues today reflected in patriarchal mentalities.

"Our social - cultural environment carries values of inherited patriarchal mentalities, which burdens the position of women, historically grown under a tradition of gender discrimination (Marku, M., Berisha, E., Gjermeni, E., Shtraza, I., 2008:16). The patriarchal tradition is very difficult to hide away from people's thoughts. It takes time and powerful developments in all areas such as economic and cultural one. Men as a group have benefited and continue to benefit from the patriarch, with the assumption that they are superior to women and should govern. But, all these benefits are associated with a price. In exchange for goods that men have benefited from the patriarch, they are required to possess women, exploit and oppress them, using violence in order to uphold the patriarch. Most men find it difficult to be patriarchs. They are troubled by the hate and scare toward women, by the men's violence against women, including men themselves who start the violence. But they are afraid to throw away these benefits. They are not sure what will happen to the world that recognize closely, if the patriarch reels. So they are easier to support male dominance, even if in their minds and hearts they know very well that such a thing is wrong (Hooks, B., 2007:13).

Generally, the patriarchal environmental study should be known in detail, as it has been the environment prior to 1990 and onwards, and a consequence of this environment today. "Today's psychological developments, even new phenomena in them, especially those controversy, cannot be completely understood without having a look to the past, to the heritage that we have had in this area, and that in a certain degree we do still have. It is a past that continues to embrace and does not let go very easily" (Beqja, H., 2000:104). Historically, human society is dominated by male dominance, which made the law in family and social life in general. Since when are boys, men listen repeatedly that "real" men are invaders toward women, that is, they control they behaviour and have the right to offend and physically abuse them. It is so important for the emergence of manhood that a man who treats a woman with equality and mutual respect relationship, sometimes behaves in the presence of other men, with a dominating attitude towards her. This behaviour makes you think that they believe that "manhood" is not something internal to men, but that it largely depends on the opinion of other men and the presence of a person or a group to be frustrated" (French, M., 2007:213).

While, women in childhood are educated not to react and obey to male dominance, because weak people should have someone strong to protect them. Physical force was and is crucial in our societies. Despite the presentation of domestic violence made in the mass media and the discussions that take place in every corner, very rarely the public correlates the end of violence with the end of masculine domination, in order to make the patriarch disappear. Most of the citizens of this nation still do not understand the connection between male dominance and male violence at home. And, 
this failure to understand is reinforced as our nation should respond to violent murders of family members, friends, classmates from the young males of all society classes. Everyone in mass media raises the question why is this violence happening, without connecting it with patriarchal thinking. (Hooks, B., 2007:143).

If you study the causes of this violence, it appears that 22.1 percent of the surveyed state that the main factor in domestic violence is patriarchal family environment and society at the same time, which tolerates and stimulates violence against women. So, the question which of the following factors do you think affect domestic violence? 18.6 percent of respondents had chosen Balkan tradition and mentality of male superiority, and 3.4 percent have chosen the way of thinking that do tolerate the violent attitudes toward women. In the same figures are also men, who for domestic violence 17.1 percent chose Balkan tradition and mentality of male superiority and 2.1 percent have chosen mindsets that tolerate violent behaviour toward women.

According to researcher Glenn Tinder: "Tradition - with this I mean the whole complex question of customs, institutions, myths, and beliefs respected by time, that arise in a society in centuries of consecutive decades". Many smart people have been thinking that tradition is the greatest wealth of a society. It represents the basic condition of human existence. The human that is naked from everything that is based on a certain tradition is not a human anymore, except in appearance, but an animal of a specific type. At least, this is the opinion of the worshipers of tradition. (Plangarica, T., 200:36).

But, as we will see, this tradition that has served our nation survived in the centuries, and had its own problems, especially in relations with women and children. Under the prevailing ideology, the traditional family, so, the patriarchal one is home safe, protected, "a shelter for a wild world". Reality shows the opposite: For women and children, family and home are dangerous places, where the risk is greater of being victims of violence and furthermore, even murder (Romito, P., 2007:142). A relationship of this kind puts the women in a difficult position, that considering the conditions of a country such as Albania, usually is associated in economical and emotional dependence, with no possibility of choice and private life.

"The role and the effect of the family in the level of domestic violence is enforced by having in mind the stereotypes regarding the role of the woman and man within the house, the myths that feed this violence and traditional patriarchal mentality that keeps alive and supports this violence. It is closely associated with traditional gender roles taught through the process of socialization. In these societies, violence against women is seen as a social mechanism that makes possible the well-definition of the boundary between the role of man and woman. In these sense, it is seen as an expression of a moral code that is a wide consensus in society (Corradi, C., 2008:69).

The individual, since when is born, has a strong connection with his mother and then with his father and the relation between them form a part of the individual's personality. The introduction in society, communication with it, giving and receiving from society, ensures the structure of the individual's personality. The process of socialization through which we pass to maturity is a process in which we learn to agree. It teaches us to agree to all rules, from the simple rules of the children games, to the laws of the institutions. There is no place for disagreement in socialization process, not for a single moment. It is believed that is better to agree. In family, school, religion or government, to disagree is not good, it's rude, dangerous." (Vassaf, G., 2010:160).

Certainly, individuals start and emerge from these frames, such as modernity that the individual embrace. But, in their subconscious, most of the impact of family and society remains. I live not just in the present, reacting against the past - think evolutions - but also live in three moments: in the past through the memory, in the present and, through projects and hopes in the future (Çapaliku, S., 2011:191). So, throughout the memory, a part of Albanian men continue to bring back in the XXI century the "Kanun", the uses of our ancestors, by calling themselves the main individuals of the house and violating their women and children.

Women are raised in a patriarchal environment, where the husband rules. He is called the man of the house and the other have to obey to him. This mechanism of authoritarianism to the people takes place in family and tribal relation. Authoritarian feelings have the form of university climate, historical and social morality, and everyday behaviour mechanism. Paternalism toward children and violence against women are commanding form, while the elderly people's orders are a form of authoritarianism in the shape of the moral tradition. Toward the education of children and young generation with fear and punishment, it is treated as the plasma of the anthrop-psychic values, in order to handle life and social mechanism. This psychic and ethic "metal" has arrived in our days and keeps the conscience invaded, not only that of normal people, but even that of the other classes of the society. The overcome of this reality is connected with leaving behind a traditional taboo, the lack of which could create a gap that takes time to fill with another moral and philosophy of life. (Kabo, P., 2006:75).

The women and the young people are pressed and cannot express freely their thoughts and make a free life. As the smallest of the society, the family is somewhat more closed, more conservative. As a micro-social environment, it 
progresses more slowly than the society. As a rule, it does not walk with the same pace with it. It remains somewhat behind, especially in the spiritual life.

Moreover, when we talk about people who are not released from the old social prejudices, strange for the democratic mentality and psychology. (Beqja, H., 1995:72). Small changes exist even between the Region of Elbasan, regarding the factors that influence in the domestic violence. The Balkan tradition and mentality of masculine superiority which tolerate the violent attitudes toward women, are the two factors that were chosen by 21.8 percent of the questioned people. In Librazhd town, these two factors were chosen by 27.7 percent, in Peqin town by 23.3 percent and in Gramsh by 26.1 percent of the questioned people. From the survey, we understand that the remote areas have chosen the tradition and mentality, while in these areas even the emancipation and economical development is very slow.

"In fact, it has some weak points, and it finds his safety in the fanatic system, which acts as shield. Another feature of his character is "carrying out" the intra-psychic conflict. The fanatic is not willing to make an internal "review" nor accept his fault. The culprits for those are the others.' (Pasini, W., 2011:85) The patriarchal behaviour in this region has been developed especially before 1945 , was fought to some extent from 45 - 90 years and still today continues to be held at this time speaking of modernization and globalization. In all the Region of Elbasan, before 1945, the big families were dominant. That means that many married people lived in the same house and were leaded by the father. In these region, there were families which had up to 50 members.

"Many travellers who arrived at night, went to sleep at the houses of Qarrishti inhabitants to spend the night. In most cases, they chose families that had better economy... These houses at that time numbered about 50 members in the family" (Biçaku, A., Hasa, A., 2012:66). The father ran these families, gave orders and everyone had to obey. In these families, the women was not asked but only had to serve.

"The direction of the first in the family was absolute and extended in every aspect of life. Without his permission, no one could leave the job, leave the place, nor could anyone get engaged. Any kind of duty that he would assign to other people, should be fulfilled with no complaint. The employees must do the job properly and obey when he ordered to go somewhere, to get married with the one assigned by the house man. Also, the money of the family was controlled by the house man. He went by himself in the market to sell different products and with the incomes he would buy anything he thought as necessary" (Hasluck, M., 2005:47). Historically, in this region, the woman was frustrated and obliged to do hard work. A discrimination for them was since they were born.

In Albania, it was a tradition that a family must have as many male children as possible, because men were evaluated as family heirs, while women were considered as "other house". The family would celeb only the birth of a son, while the birth of a daughter was seen as a disgrace. "In the past, the dinner was organized when the baby was a boy, but not when it was a girl." (Basha, P., 2011:481).

When the baby was a boy, the house man would fire a gun, to inform others the joy that a heir was born. "In most cases, when the boy was born, they shot guns: several times, three, five or seven times. When a boy was born, they said: "The house trains celebrate", "When a girl was born, the house trains cry" (Tirta, M., 2003:318).

While in Gramsh, it was considered the number of male members in the bride's family; fearing that she may give birth only to female children. "Before engaging a boy with a girl of another village (because within a village they knew her), they asked their friends if the girl had brothers. If she had, they'd prefer her as a bride, if not, they feared that she would not give birth to baby boys" (Basha, P., 2010:220).

In Albania, but even in the Region of Elbasan, during the period 1945-90, was discussed a lot about the women's rights, but in reality, a patriarchal-governmental family was created. "The woman participated actively in the productive works and any other social job, in the political and cultural life of the country, in the class and ideological war, in physical trainings and military activities, in education and massive qualifications, in amateur cultural and sportive movements. The woman's participation in all these fields was almost equal with the man's one. Exactly on this base has occurred that wonderful and unique phenomenon in the woman's life in the contemporary society - emancipation in the highest level of the woman, the highest that was ever reached in these fields, a victory that is celebrated today only by the Albanian woman." (Beqja, H., 1983, fq.148). But, this massive participation in building the socialism was done immediately after the war, because of the lack of manpower that was needed to raise up the country. "Even though after the war, the women's involvement had contributed in solving the initial lack of manpower in the country. Theoretically, women were equal to men. But, in fact, even though they were not sold as men's property anymore, they were transformed in Government's property. Women continued to work as hard in the field as they used to before the war. Practically, by maintain their traditional role as a mother, the Hoxha's regime estimated women more than it happened before the war. When she would give birth to six children, she would receive the Mother's Medal, to nine children the Glory Medal, while to twelve children, she would receive the Hero Mother Medal. But, it continued to exist a contradiction in the men's attitude who even though had accepted the role of the women in the public life, they continued to treat them as servants within the 
house. " (Vickers, M., 2008, fq.304). Women worked hard with the idea of their emancipation. They were hired in hard jobs such as construction and mining. These women were over-exhausted and begun to lose their femininity. They were transformed into men, regarding both their appearance and communication. "But, improper and hard jobs were given to women, in construction, mining, etc. It was very hard and improper the third shift for the woman. Those who have fine pretending have said that these jobs vanish the woman's femininity, their delicacy. Very difficult was even the woman's work in agriculture. They dominate in the field works and often in extended hours." (Beqja, H., 2002, fq.48).

\section{References}

Donati, Pierpaolo.: Manuale di sociologia della famiglia, Editori Laterza \& Figli Spa, Bari, 2009.

Saraceno,CH. \& Naldini,M.: Sociologia della famiglia, Mulino Bolognav 2010.

Donati,P \& Ferrucci, Fabio: Verso una nuova cittadinanza della famiglia in Europa, Franco Angeli, Milano, 1994.

Giddens, A.: Sociologjia, Shtëpia Botuese "Çabej", Tiranë, 2004.

Hasluck, Margaret: Kanuni, ligji i pashkruar, Shtëpia Botuese "Lisitan", Tiranë, 2005.

Beqja, Hamit: Edhe Ëngjëjlli, edhe djalli janë brenda te i gjalli, Shtëpia Botuese "Albinform", Tiranë, 1995.

Beqja, Hamit: Rreth edukatës qytetare, Shtëpia Botuese "8 Nëntori", Tiranë, 1983.

Kabo, Përparim: Autoritarizëm në tranzicion, Shtëpia Botuese "Plejad", Tiranë, 2006.

Vickers Miranda: Shqiptarët, një histori moderne, Shtëpia Botuese "Bota Shqiptare", 2008.

Beqja, Hamit: Problemi i edukatës socialiste dhe shkolla, Shtëpia Botuese e Librit Shkollor, Tiranë, 1987.

Tirta, Mark: Etnologjia e Shqiptarëve, Shtëpia Botuese "Geer", Tiranë, 2003.

Dervishi, Zyhdi: Ndërmjetësimi - komunikim psikokulturor kompleks, Revista "Pajtimi", nr.2, Tiranë, 1996.

Corradi, Consuelo, (Laboratorio Sociologigo): I Modeli sociali della violenza contro le donne, Franco Angeli, 2012.

Pasini, Willy, Xhelozia, Fytyra tjetër e dashurisë. Shtëpia Botuese "Skanderbeg books", Tiranë, 2006.

Beqja, Hamit: Gruaja - kjo qenie e shenjtë, botuar nga "Akademia e Shkencave", Tiranë, 2002.

Basha, Petrit; Rite dhe praktika rituale në rrethin e Gramshit. Shtëpia Botuese ....... Tiranë, 2010.

Romito, Patrica; Heshtje shurdhuese, Shtëpia Botuese "Dora D'Istria", Tiranë, 2007.

Leka, Ilmi; Allushi, Kujtim; 95 vjet shkollë shqipe në Çermenikë, Shtëpia Botuese "ASD", Tiranë, 2011.

Plangarica, Tomor; Universi i vlerave të munguara, Shtëpia Botuese "SEJKO", Elbasan, 2002.

Beqja, Hamit; Tranzicioni Demokratik dhe psikologjia e shqiptarëve të sotëm, Shtëpia Botuese "Mësonjtorja e parë", Tiranë, 2000.

Romito, Patrizia; Heshtje shurdhuese, Shtëpia Botuese "Dora D'Istria", Tiranë, 2007.

Vassaf, H.Y. Gunduz; Të burgosur të vetvetes, Shtëpia Botuese "Fan Noli", Tiranë, 2010.

Basha, Petrit; Tunja pranë kalasë, Shtëpia Botuese "Juliani 2", Tiranë, 2011.

Hooks.Bell; Feminizmi është për të gjithë, Shtëpia Botuese "Dudaj”, Tiranë, 2007. 